\title{
HUBUNGAN PENGARUH POSISI ERGONOMIK DAN HAZARD PSIKOSOSIAL TERHADAP KINERJA PERAWAT
}

\author{
Tati Oktiana Tamba
}

\section{Tatitamba26@gmail.com}

\section{LATAR BELAKANG}

Konsep ergonomik serta kesehatan dan keselamatan kerja merupakan konsep penting untuk diterapkan dalam bidang pekerjaan khususnya dalam perancangan dan perencanaan lingkungan kerja yang memadai dan tenang.Kecenderungan yang terjadi saat ini adalah konsep tersebut kurang begitu diperhatikan, sehingga dapat menimbulkan resiko kerja baik dari segi bahaya kondisi lingkungan fisik, sikap dan cara kerja (Kuswara, 2014).

Industri barang dan jasa telah mengembangkan kualitas dan produktivitas. Restrukturisasi proses produksi barang dan jasa terbukti meningkatkan produktivitas dan kualitas produk secara langsung berhubungan dengan disain kondisi kerja Pengaturan cara kerja dapat memiliki dampak besar pada seberapa baik pekerjaan dilakukan dan kesehatan mereka yang melakukannya. Semuanya dari posisi mesin pengolahan sampai penyimpanan alat-alat dapat menciptakan hambatan dan risiko.

Penyusunan tempat kerja dan tempat duduk yang sesuai harus diatur sedemikian sehingga tidak ada pengaruh yang berbahaya bagi kesehatan. Tempat - tempat duduk yang cukup dan sesuai harus disediakan untuk pekerja-pekerja dan pekerja-pekerja harus diberi kesempatan yang cukup untuk menggunakannya.

Prinsip ergonomi adalah mencocokan pekerjaan untuk pekerja. Ini berarti mengatur pekerjaan dan area kerja untuk disesuaikan dengan kebutuhan pekerja, bukan mengharapkan pekerja untuk menyesuaikan diri. Desain ergonomis yang efektif menyediakan workstation, peralatan dan perlengkapan yang nyaman dan efisien bagi pekerja untuk digunakan. Hal ini juga menciptakan lingkungan kerja yang sehat, karena mengatur proses kerja untuk mengendalikan atau menghilangkan potensi bahaya. Tenaga kerja akan memperoleh keserasian antara tenaga kerja, 
lingkungan, cara dan proses kerjanya. Cara bekerja harus diatur sedemikian rupa sehingga tidak menimbulkan ketegangan otot, kelelahan yang berlebihan atau gangguan kesehatan yang lain.

Pada saat bekerja perawat banyak melakukan aktivitas dalam posisi berdiri atau berjalan dalam jangka waktu yang cukup lama. Berputarnya tulang belakang di saat tubuh sedang membungkuk merupakan factor penyebab nyeri punggung bawah yang merupakan salah satu keluhan muskuloskletal. Aktivitas pemindahan barang secara manual dengan posisi tubuh membungkuk yang kaku yang dilakukan secara berulang-ulang merupakan penyebab terjadinya keluhan muskuloskeletal (Rizka, 2012).

Lingkungan kerja merupakan tempat dimana seseorang melakukan pekerjaan. Banyak faktor bahaya di lingkungan kerja yang dapat mengakibatkan gangguan kesehatan dan faktor psikososial karyawan. Faktor bahaya tersebut bersumber dari kegiatan dimana proses produksi berlangsung. Lingkungan dan kondisi kerja yang tidak sehat merupakan beban tambahan kerja bagi karyawan. Bahaya faktor psikososial di tempat kerja dapat berhubungan dengan lingkungan sosial kerja, yang berpotensi menyebabkan gangguan pada psikologi dan fisik-fisiologis karyawan.

Kondisi kerja yang telah berubah, dampak pada faktor risiko psikososial telah meningkat maka kinerja karyawan akan semakin rendah. Psikologis tuntutan pekerjaan adalah salah satu risiko psikososial utama dalam pekerjaan dan mengacu pada aspek pekerjaan yang akan membutuhkan usaha mental atau emosional. Meskipun tidak selalu negatif, tuntutan pekerjaan psikologis dapat memicu reaksi ketegangan dan stres ketika mereka membutuhkan terlalu banyak usaha. Jika berkelanjutan, psikologis tuntutan pekerjaan dapat mengakibatkan sakit (Niedhammer, Chastang, Sultan-Taieb, Vermeylen, \& ParentThirion, 2012).

Tujuan mengetahui hubungan pengaruh ergonomik dan hazard psikososial terhadap kinerja perawat adalah untuk menghindari penyakit atau cedera pada perawat sehingga peningkatan kualitas kinerja akan lebih baik . Dengan mengetahui ergonomik dan hazard psikososial ini, maka akan tercipta lingkungan kerja yang aman, sehat dan nyaman sehingga kerja lebih produktif dan efisien serta adanya jaminan kualitas kerja bagi setiap bidang profesi manapun, termasuk petugas kesehatan dalam hal ini profesi perawat (Kuswara, 2014). 


\section{METODE}

Metode yang digunakan pada penulisan ini menggunakan metode literature review dengan menggunakan pendekatan jurnal online, skripsi dan karya ilmiah yang akurat dan berfokus pada tema yaitu upaya mempertahankan ergonomik pada posisi dan upaya mencegah hazard psikososial. Adapun juga literatur yang digunakan pada literature review dapat diakses melalui Google Scholar, Google skripsi, dan Jurnal Keperawatan Indonesia.Literatur yang dipakai dipublikasikan tahun 2012 - 2020 dengan menambahkan atau memasukkan referensi kunci yang telah ditentukan .

\section{HASIL}

Berdasarkan juranl Amilia, E. S. (2018). Nyeri Punggung Bawah Pada Perawat IGD Dan ICU RSU Sari Mutiara Medan. E-Jurnal Kesehatan, 7. didapatkan data sebagian besar responden memiliki umur > 25 tahun, yaitu sebanyak 29 orang (93.5\%). Sebagian besar responden memiliki jenis kelamin perempuan sebanyak 23 orang (74.2\%), 20 orang (64.5\%) responden memiliki BB normal, sebagian besar responden memiliki masa kerja $\leq 5$ tahun yaitu sebanyak 27 orang $(87,1 \%), 29$ orang $(93,5 \%)$ responden mengangkat pasien $>25 \mathrm{~kg}$, rata-rata pasien yang diangkat perminggu $>3$ orang sebanyak 29 orang $(93,5 \%)$, sebagian besar responden tidak mengalami NPB, yaitu sebanyak 29 orang (93.5\%) dan sebagian besar

responden memiliki posisi kerja tidak ergonomis, yaitu sebanyak 24 orang (77.4\%). Berdasarkan hasil analisa tabel 2, didapatkan hubungan yang bermakna antara umur dengan NBP pada perawat $(\mathrm{p}=0.008)$ dan kekuatan hubungan sebesar 0.466 . Tidak ada hubungan yang bermakna antara IMT dengan NBP pada perawat $(\mathrm{p}=0.294)$ dan kekuatan hubungan sebesar 0.195. Tidak ada hubungan yang bermakna antara posisi kerja dengan NBP pada perawat $(\mathrm{p}=0.354)$ dan kekuatan hubungan sebesar -0.172 .

Posisi tubuh tidak ergonomis saat tindakan merupakan salah satu faktor risiko NPB pada perawat. Nyeri yang terjadi karena beban kerja melebihi kapasitas kerja maupun posisi kerja yang tidak ergonomis dalam menangani pasien terutama pada saat mengangkat, memindahkan pasien selama bekerja. Hubungan yang bermakna antara faktor risiko sikap tubuh membungkuk 
dengan sudut $20^{\circ}-45^{\circ}$ (fleksi sedang) dengan low back pain. Salah satu sikap perawat yang peneliti observasi dan berisiko untuk terjadinya low back pain bila dilakukan tidak secara ergonomis adalah waktu mengangkat pasien, melakukan pemasangan infus, melakukan ganti balutan luka, merubah posisi pasien dan melakukan pengukuran urine.

Hasil observasi perawat di ruang ICU didapatkan perawat melakukan pemantauan pengeluaran urin dilakukan dengan cara berjongkok atau membungkuk karena posisi urine bag berada di bawah tempat samping tidur, sehingga merupakan faktor risiko terjadinya gangguan muskuloskletal terutama di daerah ekstremitas bawah (lutut). Begitu juga pada saat pendokumentasian pemantauan hemodinamik, aktivitas kerja perawat banyak dilakukan dalam posisi berdiri dan membungkuk, baik dengan satu ataupun dua kaki karena meja observasi yang tinggi dan chart observasi yang lebar.

Hasil penelitian ini sejalan dengan penelitian Zaki (2015), yang mendapatkan bahwa insiden tertinggi LBP terjadi pada kelompok umur 36-45 tahun, sedangkan yang terendah pada kelompok umur 18-25 tahun. Hasil serupa didapat oleh Djais (2013), dimana puncak kejadian LBP pada laki-laki dengan usia rata-rata $45 \pm 13,9$ tahun. Peneliti Berasumsi bahwa dengan bertambahnya umur seseorang akan mengalami penurunan kapasitas fisik dan

kemampuan fungsionalnya. Jadi semakin tua seseorang, semakin tinggi risiko orang tersebut untuk mengalami nyeri punggung bawah hal ini terjadi karena penurunan elastisitas pada tulang, yang menjadi pemicu timbulnya gejala gangguan musculoskeletal. Berdasarkan hasil penelitian yang telah dilakukan pada pegawai di STIKes Muhammadiyah Palembang, terdapat hubungan posisi duduk dengan Low Back Pain (LBP). posisi duduk dapat menyebabkan Low Back Pain (LBP) disebabkan karena Posisi duduk yang salah dan kurang ergonomis seperti duduk dalam posisi membungkuk dapat memicu kerja otot yang kuat dan lama sehingga aliran darah ke otot terhambat. Dan dari observasi yang dilakukan oleh peneliti didapatkan bahwa beberapa kursi yang ada tidak sesuai standar ergonomic hal ini juga lah yang dapat memicu posisi duduk yang salah dan tidak ergonomic. didapatkan juga hasil umur responden. Pada saat menulis dan membaca dengan menggunakan meja dan kursi yang lama posisi kaki dan tungkai tidak alamiah. Untuk membuat posisi duduk menjadi stabil atau nyaman mereka cenderung melakukan posisi duduk yang tidak alamiah dengan cara menyandarkan pergelangan kedua kakinya di atas alas duduk teman di depannya. Posisi duduk seperti ini dapat terjadi sebagai akibat adanya 
ketidaksesuaian antropometri dengan ukuran kursi yang digunakan. Akibat posisi duduk yang tidak alamiah tersebut dapat menyebabkan merasa nyeri dan lelah pada bagian tungkai kaki, pergelangan kaki, paha, dan betisnya. Hasil penelitian juga menunjukkan bahwa pekerja dengan keluhan nyeri kaki berat sebagian besar memiliki skor postur kerja berdiri risiko tinggi, sedangkan pekerja dengan keluhan nyeri kaki ringan lebih banyak memiliki skor postur kerja berdiri dengan kategori risiko sedang. Berdasarkan hasil uji statistik dapat disimpulkan bahwa terdapat hubungan antara postur kerja berdiri dengan keluhan nyeri kaki. Berdiri dalam waktu yang lama dapat mengakibatkan perubahan pada sistem tubuh.

Berdasarkan aspek lingkungan kerja dapat dikatakan bahwa faktor fisik dan faktor kimia di lingkungan kerja dapat menimbulkan faktor psikososial bagi karyawan. Faktor fisik tersebut antara lain noise (suara bising), temperature (suhu), clean lines (kebersihan tempat kerja), faktor kimia dust (debu) dan gas. Beberapa permasalahan dalam lingkungan kerja fisik mempengaruhi kesehatan karyawan sehingga memunculkan simptom-simtom gangguan kesehatan mulai dari yang ringan hingga berat Bahaya psikososial adalah suatu bahaya non fisik yang timbul karena adanya interaksi dari aspek-aspek pekerjaan seperti desain kerja, tuntutan kerja, organisasi dan manajemen di tempat kerja serta konteks lingkungan sosial yang berpotensi menimbulkan gangguan bagi kesehatan para pekerja secara fisik, sosial dan psikologi. Bahaya psikososial dapat disimpulkan menjadi beberapa aspek berdasarkan

kategori karakteristik kerja, organisasi dan lingkungan kerja dimana dapat menyebabkan gangguan kesehatan. Hal ini menunjukkan bahwa karakteristik kerja dapat digunakan untuk menggambarkan bahaya kaitannya dengan hubungan kerja atau isi dari pekerjaan. Kondisi yang tak pasti dari aspek kerja dapat menimbulkan stress dan berbahaya bagi kesehatan. Permasalahan-permasalahan terkait kondisi fisik kerja ini harus diperbaiki oleh perusahaan karena banyaknya konsekuensi negatif yang muncul. Beberapa di antaranya adalah penuruhan kualitas kerja karyawan karena penurunan kualitas kesehatan.

\section{PEMBAHASAN}

\section{Upaya mempertahankan ergonomik pada posisi berbaring, duduk, berdiri dan berjalan}

Duduk merupakan salah satu sikap tubuh menopang batang badan bagian atas oleh pinggul dan sebagian paha yang terbatas pergerakannya. Bila aktivitas atau pekerjaan tidak dilakukan secara 
ergonomis akan menyebabkan tubuh menjadi tidak nyaman dapat pula meningkatkan resiko timbulnya nyeri punggung. Posisi dan lama duduk dalam bekerja sering diabaikan, padahal kondisi ini penting karena mengandung prinsip ergonomik. Posisi duduk mempengaruhi risiko Low Back Pain (LBP) atau nyeri punggung bawah. Otot yang mengalami kontraksi statis dalam waktu lama juga akan mengalami kekurangan aliran darah dan menyebabkan berkurangnya pertukaran energi dan tertumpuknya sisa-sisa metabolisme pada otot yang aktif, sehingga otot menjadi cepat lelah dan timbul rasa sakit, serta kekuatan kontraksi berkurang yang berakibat produktivitas kerja menurun. Maka sikap kerja yang baik mengupayakan agar postural stress yang muncul sesedikit mungkin.

Keluhan LBP dapat dikurangi dengan model posisi kerja yang ergonomis. Posisi kerja yang ergonomi membuat pekerja merasa nyaman dan tidak menimbulkan rasa lelah. Menurut Grandjen (1993) sebaiknya posisi kerja duduk-berdiri secara bergantian (perubahan posisi) untuk menghindari kejenuhan dan ketegangan otot - otot pada anggota tubuh yang statis serta mengubah sikap kerja yang monotoni menjadi lebih bervariasi dan Sanders dan Mc Cormick (1987) memberikan pedoman untuk mengatur ketinggian landasan kerja pada posisi duduk seperti menyediakan meja yang dapat diatur turun dan naik (jika memungkinkan), landasan kerja harus memungkinkan lengan menggantung pada posisi rileks dari bahu, dengan lengan bawah mendekati posisi horisontal atau sedikit menurun (Sloping down slightly) dan ketinggian landasan kerja tidak memerlukan fleksi tulang belakang yang berlebih, Sementara itu postur yang anatomis akan mengurangi kerja dari otot-otot ekstensor

untuk melawan beban yang ditransmisikan pada tulang belakang. Sehingga kemungkinan terjadinya spasme atau strain pada otot tersebut dapat dihindari. Dan juga, ketika postur dalam posisi anatomis, struktur seperti diskus intervertebralis mendapat pembebanan yang seimbang pada bagian anterior, posterior, dan lateralnya. Sehingga kemungkinan terjadi kerusakan struktur bagian posterior dari tulang belakang yang pain sensitive dapat dicegah.. Contohnya Meja dan kursi yang digunakan harus disesuaikan dengan ukuran antropometri siswa dan sesuai dengan prinsip perancangan yang ergonomis (Santoso, 2012). Kaidah Ergonomi dalam mendesain tempat duduk sangat penting diperhatikan dalam proses pembelajaran. Agar tempat duduk nyaman dipakai pada waktu belajar, maka ukuran-ukurannya harus disesuaikan dengan antropometri orang yang akan memakainya. Penerapan meja dan kursi yang ergonomis dapat 
mencegah lebih dini berbagai gangguan kesehatan siswa di masa dewasanya nanti dan membentuk sikap tubuh yang benar, mengurangi kelelahan, lebih berkonsentrasi dan akhirnya secara keseluruhan akan dapat meningkatkan sumber daya manusia untuk lebih berkualitas baik dari segi derajat kesehatannya maupun pada peningkatan kemampuan/konsentrasi dalam belajar (Lin, et al., 2014; Santoso, 2012; Sutajaya, 2007).

Sikap kerja berdiri dalam waktu lama akan membuat pekerja selalu berusaha menyeimbangkan posisi tubuhnya sehingga menyebabkan terjadinya beban kerja statis pada otot-otot punggung dan kaki. Kurangnya aliran darah mempercepat timbulnya kelelahan, ketidaknyamanan dan menyebabkan nyeri serta ketegangan pada otototot punggung, kaki dan leher (otot yang digunakan untuk mempertahankan posisi tegak). Berdiri terlalu lama dan sering, tanpa bantuan dengan berjalan kaki, menyebabkan darah berkumpul di kaki. Ketika berdiri terjadi terus menerus selama waktu yang lama, dapat mengakibatkan radang pembuluh darah. Peradangan ini dari waktu ke waktu berkembang menjadi varises kronis dan menyakitkan. Selain itu juga bisa menyebabkan sendi di tulang belakang, pinggul, lutut dan kaki menjadi seperti terkunci yang nantinya memicu terjadinya penyakit rematik degeneratif akibat kerusakan pada tendon dan ligamen (struktur yang mengikat otot tulang).

Upaya mempertahankan posisi ergonomis misalnya melakukan peregangan dan relaksasi ditempat atau sekedar berjalan, mengganti posisi tubuh saat terasa nyeri dengan posisi yang lebih nyaman, menahan rasa nyeri hingga berkesempatan untuk istirahat, dan sebagainya. Dengan kata lain semua pekerja memilliki kemungkinan yang sama dalam mengalami rasa nyeri kaki dan yang membedakan ialah faktor individu sendiri.

\section{Upaya mencegah hazard psikososial}

Hazard psikososial merupakan factor dan situasi yang berkaitan dengan tempat kerja atau lingkungan kerja yang dapat memicu stress, ketegangan emosioanl dan masalah interpersonal. Dalam pandangan keselamatan dan kesehatan kerja dapat merupakan tempat beresiko bagi tenaga kerja untuk mengalami gangguan kesehatan atau mengalami kecelakaan kerja. Masalah psikososial merupakan masalah psikis atau kejiwaan yang timbul sebagai akibat terjadinya perubahan social. Bahaya psikososial dapat menyebabkan stres pada pekerja, hal ini dapat disebabkan oleh akumulasi stressor pada situasi kerja di tempat kerja. Misalnya, tuntutan 
pekerjaan dapat memicu timbulnya stres di tempat kerja. Menurut Randall R. Ross (1994), disebutkan bahwa stres kerja terjadi akibat adanya interaksi antara kondisi kerja dengan karakteristik pekerja dimana tuntutan pekerjaan melebihi kemampuan para pekerja. Oleh karena itu, masalah atau bahaya psikososial dapat terjadi sebagai akibat atau dampak negatif dari adanya proses interaksi sosial seseorang yang buruk. Resiko kerja dan gangguan kesehatan tersebut dapat merugikan para pekerja, yang dapat mengakibatkan pekerja meninggal, keracunan, cacat dan mengidap penyakit kronis sehingga tidak mampu lagi untuk bekerja. Dari bahaya tersebut bahaya terpajan bahaya psikososial dapat dipastikan akan dihadapi oleh seluruh tenaga kerja yang dapat menimbulkan stress kerja dan menjadi masalah bagi kesehatan dan keselamatan kerja.

Upaya mencegah hazards keselamatan kerja dan lingkungan dalam area lingkungan kerja, perawat penting untuk mengidentifikasi agent yang berkaitan dengan pekerjaan dan paparan yang dapat berpotensi sebagai hazard. Upaya mencegah hazard psikososial ada pencegahan primer, sekunder dan tersier. Pencegahan primer yaitu perawat kesehatan kerja dilibatkan dalam upaya promosi kesehatan maupun pencegahan penyakit. Pengenalan terhadap resiko kesehatan ini diikuti oleh berbagai langkah. Perawat kesehatan kerja menggunakan metode yang bervariasi untuk pencegahan primer, dengan interaksi one-one sebagai sebuah strategi yang sangat penting dalam mengevaluasi perilaku penurunan risiko bagi pekerja. Perawat kesehatan kerja merencanakan, mengembangkan, mengimplementasikan, dan mengevaluasi strategi intervensi yang berfokus pada agrerat. Selanjutnya pencegahan sekunder yang ditujukan pada diagnose awal, intervensi penanganan awal. Perawat kesehatan kerja diberikan kesempatan untuk melakukan pengkajian, penilaian dan memberikan penanganan serta rujukan pada berbagai kondisi fisik dan psikologis dengan memberikan penanganan atau intervensi langsung pada penyakit. Dan yang terakhir pencegahan sekunder yaitu perawat kesehatan kerja memainkan peran kunci dalam rehabilitasi dan pemulihan pekerjaan dari pekerja untuk mencapai fungsi kesehatan pada tahap level yang optimal. Strategi yang dilakukan termasuk pada managemen kasus, negosiasi, untuk akomodasi tempat konseling serta dukungan untuk pekrja yang mengalami penyakit. Dan tindakan lain yang dapat dilakukan untuk mengatasi hazard psikososial adalah maka perlu dilakukan identifikasi bahaya, dimana penyakit akibat kerja bisa disebabkan oleh perilaku pekerja dan kondisi tempat kerja yang kurang baik. 


\section{PENUTUP}

Terdapat hubungan antara ergonomi kerja perawat terhadap timbulnya gangguan kesehatan akibat kerja, yang mana paling banyak adalah nyeri pinggang, nyeri lutut, dan pusing.Sikap duduk ergonomis efektif dapat menurunkan nyeri punggung. Pendidikan dan pelatihan ergonomi dan sikap kerja yang benar harus diperkenalkan di tempat kerja untuk mengurangi resiko keluhan penyakit nyeri pinggang begitu juga dengan hazard psikososial.

Diharapkan pekerja ketika melakukan kegiatan tetap memperhatikan posisi yang ergonomi dan menurunkan hazard psikososial pada pihak instalasi mampu memberikan kursi pada pekerja dengan standar kursi yang ergonomis guna mencegah timbulnya kejadian penyakit nyeri punggung dan memanfaatkan waktu istirahat yang diberikan dengan kegiatan yang menyehatkan baik untuk kesehatan kondisi psikologis dan kesehatan tubuh. Semua pekerjaan perawat harus dilakukan secara benar dalam posisi ergonomic dan penurunan hazard psikososial dalam melakukan tindakan dapat menentukan kualitas kerja

\section{DAFTAR PUSTAKA}

1. Amilia, E. S. (2018). Nyeri Punggung Bawah Pada Perawat IGD Dan ICU RSU Sari Mutiara Medan. E-Jurnal Kesehatan, 7.

2. Andarini Desheila, Pacu Putra, Maya Puspasari, Ani Nidia Listianti, Sasviana Putri. 2019. Indentifikasi Bahaya Psikososial Pada Buruh Wanita di Pabrik Karet. Jurnal Kesehatan No1.

3. Angraika Putri, Anita Apriliany, Dewi Pujiana. 2019. Hubungan Posisi Duduk Dengan Low Back Pain (LBP) Pada Pegawai Stikes. Jurnal Aisyiyah Medika Vol 4(1)

4. Angrianti Maulina Siska, Bina Kurniawan, Baju Widjasena.2017. Hubungan Antar Postur Kerja Berdiri Dengan Keluhan Nyeri Kaki Pada Pekerja Aktivitas Mekanik Section Welding di PT X.

5. Balaputra ishana, Adi Heru Sutomo. 2017. Pengetahuan Ergonomi dan Postur Kerja Perawat Pada Perawatan Luka Dengan Gangguan Muskuloskletal Di dr.H. Koesnadi Bondowoso. BKM Journal Of Community Medicine And Public Health Vol 33(9) 
6. Daniah , Rizki Zulfikri Fauzi.2016. Hubungan Gejala Stress Dengan Bahaya Psikososial Pada Pekerja Pengumpul Tol Cabang Jagowari Di PT.Jasa Marga (Persero) TBK tahun 2016. Jurnal Ilmu Kesehatan,8(2)

7. Harwanti Siti, Budi Aji, Nur Ulfah. 2016. Pengaruh Posisi Kerja Terhadap Low Back Pain (LBP) Pada Pekerja Batik Di Kauman Surakarta. Jurnal Kesmas Indonesia Vol 8(1)

8. Kemala Aliva. 2018. Faktor Psikososial Lingkungan Kerja (Studi Kasus) Pada Karyawan Pabrik SSP PT X. Jurnal Psikologi Vol 11(1)

9. Nies A Mary, Melanie McEwen. 2019. Keperawatan Kesehatan Komunitas dan kelurga. Singapura: Elsevier

10. Nilamsari Nefrety, Soebijanto, Lientje, Setokoesoemo.2015. Prototype Bangku Ergonomis Untuk Memperbaiki Posisi Duduk Siswa SMAN di Kabupaten Gresik. Jurnal Ners Vol 1(1)

11. Primasari Annisa Devi , Hanifa Maher Denny, Ekawati. 2016. Penerapan Hazard Identifiation Risk Assesment And Risk Control (Hirarc) Sebagai Pengendalian Potensi Kecelakaan Kerja Di Bagian Produksi Body Bus PT.X Magelang. Jurnal kesehatan Masyarakat (e-Journal).

12. Simamora, R. H. (2020). Learning of Patient Identification in Patient Safety Programs Through Clinical Preceptor Models. Medico Legal Update, 20(3), 553-556.

13. Fathi, A., \& Simamora, R. H. (2019, March). Investigating nurses' coping strategies in their workplace as an indicator of quality of nurses' life in Indonesia: a preliminary study. In IOP conference series: Earth and Environmental science (Vol. 248, No. 1, p. 012031). IOP Publishing. 